\title{
OCCURRENCES OF THE AMPHI-ATLANTIC BROWN MUSSEL Perna perna (LINNÉ, 1758) (MOLLUSCA, BIVALVIA) IN SOUTH PORTUGAL SINCE THE ATLANTIC "CLIMATIC OPTIMUM"
}

\author{
Pedro Miguel Callapez(1), Randi Danielsen(2) \& Ana CAstilho(3)
}

\begin{abstract}
:
The large, edible, and near-cosmopolitan brown mussel Perna perna (LINNÉ, 1758) has a history of few and infrequent occurrences in Portugal since the Atlantic "climatic optimum" of the Holocene. Moreover, it is likely that some previous citations of Mytilus spp. from other Holocene deposits, including kitchen middens, may represent true Perna specimens. The species was recently found by Lourenço et al. (2012) in the south Portuguese coastal localities of Ilha do Farol and Vila Moura. Here, we summarize these and other previously published occurrences of P. perna in the areas of Armação de Pêra, Lagos and Aljezur, discussing morphologic, ecologic and biogeographic aspects of this species in the Portuguese fauna. The brown mussel is also known from archaeological records from Padrão I (Sagres - Vila do Bispo, Ancient Neolithic) and Arrifana (Aljezur, XII century). These chronologies are contemporaneous with the climatic warming intervals of the Atlantic Period (circa 8000-5000 BP) and "Medieval Warm Period" (circa 10001200 AD). During these and other related intervals of warmer coastal surface waters, it is very likely that this subtropical "warm guest" colonized open marine rocky areas of the South and Southwest Portuguese coast, with settlement of stable and permanent populations.
\end{abstract}

Keywords: Marine molluscs; Perna perna; Holocene; Biogeography; Portugal.

Resumo:

\begin{abstract}
Ocorrências do mexilhão castanho anfiatlântico Perna perna (Linné, 1758) (Mollusca, Bivalvia) no sul de Portugal desde o "ótimo climático" Atlântico

O mitilídeo Perna perna (LinNÉ, 1758), espécie comestível de dimensão apreciável e repartição quase cosmopolita, apresenta um historial escasso de ocorrências em Portugal desde o "ótimo climático" Atlântico do Holocénico. É provável, também, que algumas das ocorrências publicadas de Mytilus spp. noutros depósitos holocénicos, incluindo concheiros, possam corresponder a espécimes de Perna. Recolhas recentes na costa sul de Portugal, mencionadas por Lourenço et al. (2012) ampliam as ocorrências conhecidas às localidades de Ilha do Farol e de Vila Moura, em paralelo com citações mais antigas para Armação de Pêra, Lagos e Aljezur. Estas ocorrências são sumariadas no presente estudo, assim como discutidos aspetos de ordem morfológica, ecológica e biogeográfica relativos à presença desta espécie na fauna portuguesa. No registo arqueológico, o mexilhão castanho é conhecido nos arqueossítios de Padrão I (Sagres - Vila do Bispo, Neolítico Antigo) e Arrifana (Aljezur, século XII). Estas cronologias são coevas com os intervalos de melhoria climática do período Atlântico (circa 8000-5000 BP) e de finais da Idade Média (circa 1000-1200 DC). Durante estes e outros intervalos comparativos de melhoria das condições hidroclimáticas das águas superficiais costeiras, considera-se bastante provável que este "warm guest" subtropical tenha atingido, por diversas vezes, áreas não restritas do litoral rochoso do sul e sudoeste de Portugal, com o estabelecimento de populações estáveis e permanentes.
\end{abstract}

Palavras-chave: Moluscos marinhos; Perna perna; Holocénico; Biogeografia; Portugal.

\section{INTRODUCTION}

The brown mussel Perna perna (LinNÉ, 1758) is a well-known edible mollusc and an important food resource with economic impact in many low latitude coastal areas of South America, West and East Africa. Archaeological evidence also suggests that this abun- dant and rather large species has long been part of the shellfish gathering and food strategies followed by pre-historic groups since the Palaeolithic (RIUS et al., 2006). The human exploitation of this intertidal bivalve has been revealed from the study of several African archaeological sites of various ages, often from kitchen middens (JERARDINO \& MAREAN, 2010;

(1) Departamento de Ciências da Terra e Centro de Geofísica da Universidade de Coimbra - FCT; Largo Marquês de Pombal, 3001-401 Coimbra, Portugal.callapez@dct.uc.pt

(2) Laboratory of Archaeosciences, DGPC and LARC/CIBIO/InBIO, Rua da Bica do Marquês 2, 1300-087 Lisbon, Portugal. randidanielsen@gmail.com

(3) Departamento de Ciências da Terra e Centro de Geociências da Universidade de Coimbra - FCT; Largo Marquês de Pombal, 3001401 Coimbra, Portugal. amcastilrlopes@gmail.com 
LANJEANS et al., 2012). Nevertheless, its occurrence in Brazilian "sambaquis" (local designation for kitchen middens) was not confirmed after an exhaustive sampling analysis made by Souza et al. (2003). These authors also suggest that the recent Western Atlantic populations may have resulted from an exotic introduction initiated after 1500 , by passive transport of individuals byssally attached to the hulls of slave ships in route from the West African coast.

Perna perna is a typical mytilid bivalve with tropical to subtropical affinities, showing a wide latitudinal distribution in the seashores of the Atlantic and West Indian oceans (RODRIGUEZ \& J. SANCHÉZ, 1993). In subtropical West African areas it occurs side by side with typical elements of the "Senegalese Fauna" (GIGNOUX, 1913), which colonized the Western Mediterranean several times in the past. Thus, like many similarly warm water species, we can assume that the biogeographic range boundaries of this mussel have been repeatedly influenced by major changes in the hydroclimatic conditions of surface waters.

This was especially apparent during Pleistocene warming intervals, including the Post Würmian climatic optimum that culminated with the so called "Flandrian" transgression, when the effects of a worldwide millenary trend of sea-level rise caused large changes in the physiography and overall landscapes of the Portuguese coast (GRAnJA \& DE Groot, 1996; Granja, 1998; DiAs et al., 2000; DANIELSEN et al., 2011).

How and when these positive coastal surface water temperature variations made feasible the northward migration of west African or Mediterranean pelagic mollusc larvae to the Atlantic seashore of Portugal is an open question, especially since the existence of Quaternary marine deposits with thermophilic faunas has never been recognized in Portugal, as opposed to those of southern Spain (e.g., ZAZO et al., 2003).

Specimens of the brown mussel Perna perna have been found recently in rocky intertidal areas of central Algarve, in the southern Portuguese coast (LOURENÇO et al., 2012). These authors stated that this was the first find of this species in the European Atlantic coast. However, considering the post glacial biogeography of this mytilid, this occurrence instead should be seen as the younger of several repeated attempts of colonization in Portuguese waters, at least since the Atlantic "climatic optimum" (Fig. 1).

This paper summarises the previously known occurrences of this "warm guest" in the Holocene and recent molluscan faunas of the Portuguese coast, discussing morphologic, ecologic and biogeographic aspects of this species in the Portuguese fauna, and its importance in archaeological contexts.

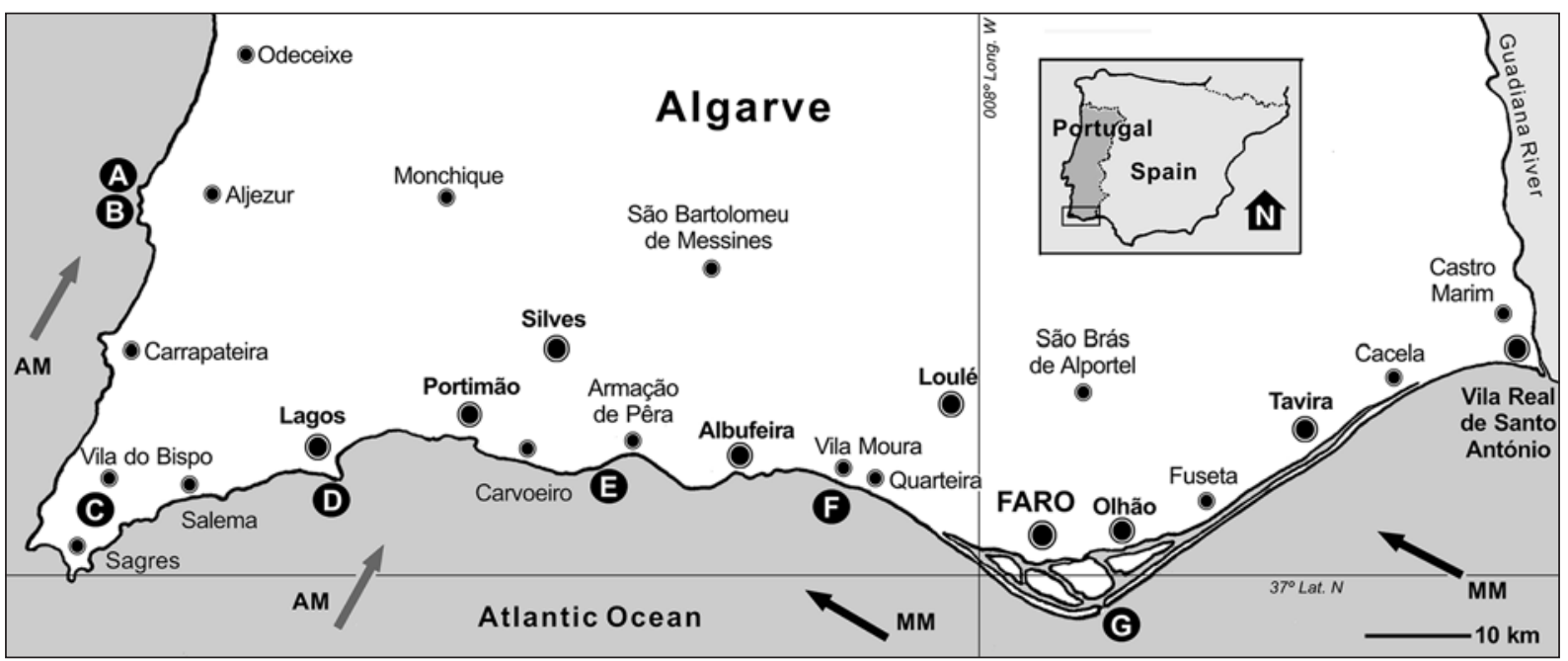

Fig. 1. Published occurrences of the brown mussel Perna perna (LinNÉ, 1758) in the south and southwest Atlantic coast of Portugal, including those related with Holocene deposits. A - Aljezur (recent), B - Arrifana (XII century kitchen middens), C - Padrão I (Ancient Neolithic kitchen midden, in press), D - Lagos (recent), E - Armação de Pêra (recent), F/G - Vila Moura and Ilha do Farol (recent, after Lourenço et al., 2012), AM - Inferred larval migration from the Atlantic seashore of Morocco, MM - Possible Western Mediterranean source.

Fig. 1. Ocorrências publicadas do mexilhão castanho Perna perna (LINNÉ, 1758) nas costas atlânticas sul e sudoeste de Portugal, incluindo as relativas a depósitos de idade holocénica. A - Aljezur (recente), B - Arrifana (XII concheiros do século XII), C - Padrão I (concheiro do Neolítico Antigo, no prelo), D - Lagos (recente), E - Armação de Pêra (recente), F/G - Vila Moura e Ilha do Farol (recente, segundo Lourenço et al., 2012), AM - Migração larvar inferida a partir do litoral atlântico de Marrocos, MM - Possível origem a partir do Mediterrâneo ocidental. 


\section{SYSTEMATIC DESCRIPTION}

The taxonomic subdivisions presented here are based on Carter et al. (2011) for the higher names above the family, and Moore (1969) for the remaining. A detailed synonymy of this species would be very large and is beyond the scope of this work, except for specific references to Portugal (with an asterisk) and to the Atlantic Northwest African coast. The systematic description is based on typical West African specimens, namely those from Morocco, Canaries, Angola and Namibia.

Filo Mollusca LINNÉ, 1758

Class Bivalvia LINNÉ, 1758

Infraclass Pteriomorphia BEURLEN, 1944

Order Mytilida FÉRUSSAC, 1822

Superfamily Mytiloidea RAFINESQUE, 1815

Family Mytilidae RAFINESQUE, 1815

Subfamily Mytilinae RAFINESQUE, 1815

Genus Perna RetZIUS, 1788

[type-species: P. magellanica $=$ Mya perna LINNÉ, 1758 by subsequent designation]

(For a detailed discussion of this genus see SIDDALL, 1980)

Perna perna (LINNÉ, 1758)

[plate I, figs. 1-7]

*1906 - Mytilus pictus, BORN - A. NOBRE, p. 113.

*1932 - Mytilus pictus BORN - A. NOBRE, pp. 295-6, 444, pl. 53.

*1938-40 - Mytilus pictus BorN - A. NoBre, p. 571, pl. 60. 1984 - Perna picta (VON BORN, 1786) - VAN AARTSEN et al., p. 58.

1993 - Perna perna (LinnAeus, 1758) - G.T. PopPE \& Y. GoTO, pl. 5, figs. 10a-b.

1997 - Perna perna (LinNEO, 1758) - R. RoDRIGUEZ \& J. SANCHÉZ, p. 135 [with figure].

*1999 - Perna perna (LinNAEUs, 1758) - MACEDo et al., p. 384, 2 figs.

*1999 - Perna picta (Von BorN, 1778) - MACEDo et al., p. 384, 1 fig.

2004 - Perna perna (LinNaEUs, 1758) - R. ARdovini \& T. Cossignani, pp. 48, 261 [with figure].

*2007a - Perna perna (LinNÉ, 1758) - P.M. CALlaPEZ, pp. 87, 90 .

*2011a - Perna perna (LinNÉ, 1758) - P.M. CALlaPeZ, pp. 168, 170, 172, 174, 177, pl. 1, fig. 4a-b, pl. 2, figs. 1ab, 2,3 .

*2011b - Perna perna (LINNÉ, 1758) - P.M. CALlAPEZ, [in press].

2011 - Perna perna (LinNAEUS, 1758) - HERNANDÉz et al., pl. 103, figs. L.-M.

*2012 - Perna perna (LinNaeus, 1758) - LoURENÇO et al., pp. 1-4, fig. 1 .

*2012 - Perna perna (LinNé, 1758) - P.M. CALlaPeZ, [in press].
Diagnosis: Medium to large, elongate and rather solid shell, cylindrical to wedge-shaped, with terminal umbonal areas. Exterior surface with a yellowish, greenish or purplish-brown to dark-brown periostracal layer, weakly ornamented with many concentric growth lines. Inner side mother-of-pearl with pinkish irisations. Dysodont hinge with tooth and a resilial ridge. Posterior adductor muscle scar well marked and separated from the retractor one.

Discussion: The specimens figured by Nobre (1932, 1938-40) and Macedo et al. (1999) show the typical morphology of West African shells (Plate I, Fig. 1). The same "cigar-like" shape (POPPE \& Goto, 1993) is found in specimens from the kitchen middens of Arrifana (Aljezur) (Plate 1, Figs. 5-7). On the contrary, the valve figured by Lourenço et al. (2012) and the specimen figured by Macedo et al. (1999) as Perna picta are from smaller and flatter individuals that match with the Western Mediterranean Perna picta (BORN, 1780). This taxon is considered by many authors as an ecomorph of the cosmopolitan Perna perna (e.g., SIDDALL, 1980). However, it should be stated that this opinion is not universal, as conchologists like Nordsieck (1969) and Poppe \& Goto (1993) have an opposite judgment.

\section{Habitat and Biogeographic RANGe}

Perna perna is a byssate mytilid bivalve found in a variety of rocky substrates from intertidal, normal salinity environments periodically exposed to rather high hydrodynamic conditions, which often result in shell breakage. Personal observations from the seashore of Angola (Benguela, Bentiaba and Namibe areas) and western Namibia (Walvis Bay, Swakopmund and Cape Cross), show that this species forms large concentrations of cylindrical individuals byssated to other shells or directly to a hard substrate, thus enabling the group to resist strong swells (named "calemas" storms in Angola). Factors like wave exposure, tidal height and relative vertical position in the intertidal shore also influence these concentrations and the whole population structure (MCQUAID et al., 2000).

According to Hicks \& McMahon (2002), the seasonal ambient water temperature range of Perna perna is well documented and limited to $10^{\circ}-30^{\circ} \mathrm{C}$. From this, the $10^{\circ} \mathrm{C}$ lower limit is a constraint that inhibits the species from successfully colonizing the Atlantic European waters, except for periodic attempts in the Algarve and on the Southwest Portuguese seashore. On the contrary, the upper range 
of $30^{\circ} \mathrm{C}$ explains why this mussel species cannot survive in truly tropical environments of the equatorial Atlantic and Indian oceans (HICKS \& MCMAHON, op. cit.).

The recent biogeographic range of Perna perna spans across large coastal areas of the Indian and Atlantic oceans, as well as the Red Sea and Mediterranean if we consider $P$. picta to be an ecomorph, as stated above. This distribution pattern is disjointed along the East coast of Africa and both sides of the Atlantic (SIDDALL, 1980; VAKILY, 1989), a fact that can be explained by the temperature tolerance of the species. However, it may have occurred larval interchange between populations from the Northern and Southern hemispheres during glacial intervals of the Pleistocene, thus temporarily changing the biogeographic range to a contiguous distribution pattern.

The northwest African range includes Morocco, Mauritania, Senegal (SIDOUMOU et al., 2006) and Ghana (OTCHERE, 2003). In the Canaries the species is more abundant in Lanzarote and Fuerteventura (HERNANDÉz et al., 2011), possibly due to local environmental conditions. It is apparently absent from the tropical seashores of Nigeria and Gabon (BERNARD, 1984).

The southwest African range is centered in Congo (CAIRÉ, 1981), Angola and Namibia (RolÁN \& RYALL, 1999; personal observation) until Luderitz Bay and more rarely the Cape coast of South Africa (KILBURN \& RIPPEY, 1982; STEYN \& LUSSI, 1998). There is also another discontinuous range from False Bay, in South Africa, to Central Mozambique (KILBURN \& RIPPEY, 1982) and Tanzania (SPRY, 1964), which establishes the transition to the Western Indo-Pacific realm populations of this species.

Additional native areas of Perna perna include Madagascar, the Red Sea, southern India and Sri Lanka (SIDDALL, 1980). On the west side of the Atlantic Ocean, the brown mussel range includes Uruguay, Brazil, Venezuela and the West Indies, with a recent introduction into the Gulf of Mexico (HICKS et al., 2001).

An interesting problem to solve is whether the larval migration of Perna to the Portuguese seashore is (and was) exclusively from a West African source, or if there is an alternative Western Mediterranean contribution. A Meditterranean source existed, for example, for Naticarius gastropods, with confirmed finds of $N$. cruentatus (GMELIN, 1791) [=N. hebraeus (MARTYN, 1786)] in the recent faunas of the Tavira area (East Algarve), and N. punctatus (CHEMNITZ, 1789) in Holocene sands dredged from Lavradio (Mar da Palha, near Lisbon) (CALLAPEZ, 2011b).

\section{History OF OCCURRENCES IN THE RECENT Portuguese Fauna}

The first documentation of Perna perna along the Atlantic coast of Europe were specimens collected around 1888, by Adolfo Moller, in slate and greywacke intertidal cliffs from the seashore of Aljezur, a well-known locality along the southwest border of Portugal. Moller was a botanist of German heritage, and an enthusiastic collaborator with the Natural History Museum at the University of Coimbra, at the time of Albino Gilraldes and Paulino de Oliveira (BURNAY \& MONTEIRO, 1988). These specimens were offered to the large conchological collections of the Museum and soon after cited by Augusto Nobre (1906) as Mytilus pictus Born: "Les exemplaires recueillis par A. Moller sont d'un grand développement, et semblables à ceux qui existent au Musée de Zoologie de l'Académie Polytechnique de Porto, provenants de l'Afrique occidentale, d'Angola" [The specimens collected by A. Moller are very large and are close to those housed at the Zoological Museum of the Polytechnic Academy of Porto, collected in West Africa, from Angola].

This comparison is interesting to note, because, as mentioned, the common West African Perna perna (LINNÉ, 1758) has an elongated cylindrical shape and can reach up to $200 \mathrm{~mm}$ in length. This contrasts with the Mediterranean specimens usually mentioned as Perna picta (BORN, 1780), which is flatter, smaller and has more ornamented valves. For several authors, such as Poppe \& Gotto (1993), these populations may belong to a different species circumscribed to the western part of the Mediterranean Sea.

By the end of the XIX century, the Portuguese King D. Carlos I led several oceanographic campaigns on the Portuguese coast, with the help of the naturalist Albert Girard (CALLAPEZ, 2007b) who researched the Algarve coast during 1898, 1899 and possibly afterwards. The royal collections assembled during that period are held at the Vasco da Gama Aquarium, and were used by Macedo et al. (1999) for revision of the Portuguese marine molluscs. They include specimens of Perna perna from the southwest coast of Algarve and Armação de Pêra.

In his extensive monograph on the marine molluscs of Portugal ("Fauna Malacológica de Portugal") Nobre (1932) first figured a large specimen of the brown mussel from Portuguese waters (Plate I, Fig. 1), with mention of new finds made by Paulino de Oliveira near the Lagos area (West Algarve). The same shell was figured again, in 1938, together with two additional specimens collected in Lagos by Nobre himself (NOBRE, 1938).

Thus, with the important finds noted by Lourenço 
et al. (2012), the modern occurrence of Perna perna in Portugal can be confirmed from five separate localities of the south and southwest coast, namely Ilha do Farol (Faro), Vila Moura, Armação de Pêra, Lagos and Aljezur (Fig. 1).

\section{Finds in Portuguese Archaeological CONTEXTS}

The taxonomic identification of Perna perna specimens from ancient deposits and archaeological contexts can be confounded by some apparent similarities with larger shells of Mytilus galloprovincialis LAMARCK, 1819, especially uncoloured fragments without preserved hinge parts or the diagnostic muscle scars.

Nevertheless, detailed work has revealed that the brown mussel is found in Ancient Neolithic and Islamic contexts of South Portugal, where the taphonomic evidence suggests its use as an edible shellfish species (CALLAPEZ, 2007a, 2011a, 2011b, 2012).

On the site of Padrão I (Vila do Bispo), one of the Ancient Neolithic sites of West Algarve, the local economy included the shellfish gathering of molluscs and other invertebrates across the local rocky shore, with emphasis on Patella intermedia MURRAY, 1857, P. ulyssiponensis GMELIN, 1791, Mytilus galloprovincialis LAMARCK, 1819, Perna perna (LinNé, 1758) (Plate I, Figs. 2-4), Stramonita haemastoma (LINNÉ, 1767) and Pollicipes pollicipes (GMELIN, 1790).

The large kitchen middens ("concheiros") from the XII Islamic site of the Arrifana Ribāt (Aljezur) are the best indirect evidence of a permanent population of Perna perna along the Portuguese seashore (Plate I, Figs. 5-7). The brown mussel was exploited as a food source, together with large limpets, trochid gastropods, Stramonita haemastoma (LINNÉ, 1767) and Pollicipes pollicipes (GMELIN, 1790). The studied invertebrate fauna totals 61 species from a sum of 114108 counted shells and fragments. This wide bulk sample was the result of a repeated exploitation of food resources available in the natural seashore environment, when it was not yet affected by extensive shellfish gathering or other anthropic activities.

\section{CONCLUSiOnS}

The near cosmopolitan and edible brown mussel Perna perna (LINNÉ, 1758) is quite rare in the recent non-insular Portuguese fauna of marine molluscs. The few registered occurrences include specimens from the late XIX and XX centuries collected by several naturalists, and described and figured by A. Nobre (1906, 1932, 1938-40) and Macedo et al. (1999).
More recently, new localities have been added by Lourenço et al. (2012), an important find that suggests a limited but permanent settlement of this subtropical edible mussel in the southern and southwestern Portuguese coasts. These new occurrences comprise the localities of Ilha do Farol and Vila Moura, adjacent to older finds by Nobre and Macedo et al. from Armação de Pêra, Lagos and Aljezur (NoBRE, 1906, 1932, 1938-40; MACEDO et al., 1999). In the archaeological record, the brown mussel is known from Padrão I (Sagres - Vila do Bispo, Ancient Neolithic) (Plate I, Figs. 2-4) and it was recently described from the Arrifana Ribāt (Aljezur, XII century) (Plate I, Figs. 5-7). The chronologies of these sites are within the climatic warming intervals of the Atlantic period (circa 8000-5000 BP) and "Medieval Warm Period" (circa 1000-1200 AD). It is also likely that some previous citations of Mytilus spp. from other Holocene deposits could be of Perna perna specimens.

During these and other intervals of warmer coastal surface waters, it is very likely that this subtropical "warm guest" colonized open marine rocky areas of the Portuguese Atlantic coast, with settlement of stable populations. The temperature tolerance of Perna perna also seems to allow a modern occurrence (XIX century to present day) and a possible settlement of limited populations.

Finally, the existence of typical northwest African "cigar-shaped" specimens, together with morphologies closer to Mediterranean Perna picta ecomorphs, may suggest possible sources of larval migration both from the Atlantic Moroccan and Western Mediterranean areas.

\section{ACKNOWLEDGEMENTS}

Authors wish to offer thanks to Prof. Mário Varela Gomes (New University of Lisbon) for the studied material from the kitchen middens of Arrifana and Sagres, as well as for a review of the text. Our thanks also go to Prof. Jocelyn Sessa (Smithsonian Institution and National Museum of Natural History) for the critical review of the manuscript, and to Prof. Pedro Dinis (University of Coimbra) for his kind and helpful collaboration in the publication of this paper. The present research was supported by the Centro de Geofísica da Universidade de Coimbra (CGUC-FCT).

\section{REFERENCES}

Ardovini, R. \& Cossignani, T. 2004. West African Seashells. Ancona, Italy: l'Ínformatore Piceno Publ.

Bernard, P.A. 1984. Coquillages du Gabon / Shells of Gabon. Libreville, Gabon: Author Ed. 
Beurlen, K. 1944. Beiträge zur Stammesgeschichte der Muscheln. Mathematisch-Naturwissenschaftlichen. Abteilung der Bayerischen Akademie der Wissenschaften zu München, Sitzungsberichte, 1944 (1-2): 133-145.

Burnay, L.P. \& Monteiro, A. 1988. História da Malacologia em Portugal. Publicações Ocasionais da Sociedade Portuguesa de Malacologia, 12: 1-123.

Callapez, P.M. 2007a. Fauna Malacológica do Ribāt da Arrifana - Análise preliminar. In R. VAREla Gomes \& M. VARELA GOMES (eds.), Ribāt da Arifana. Cultura material e espiritualidade. Aljezur: Associação de Defesa do Património Histórico e Arqueológico de Aljezur: 87-90.

CAllapez, P.M. 2007b. Alberto Girard (1860-1914), notável naturalista português. Boletim da Associação Portuguesa de Professores de Biologia e Geologia, 28: 48-51.

CALlaPeZ, P.M. 2011a. Estudo zooarqueológico dos invertebrados do Ribāt da Arrifana (Aljezur, Portugal). Sua relação com as comunidades marinhas litorais e com hábitos alimentares no algarve muçulmano do século XII. In R. VARELA GOMES, M. VAREla GoMes \& C. Tente (eds.), Cristãos e Muçulmanos na Idade Média Peninsular. Encontros e Desencontros. Lisboa: Instituto de Arqueologia e Paleociências das Universidades Nova e do Algarve: 165-186.

CAllapez, P.M. 2011b. Os moluscos portugueses em contextos arqueológicos: importância e estado da arte. Xelb, Revista de Arqueologia, Arte, Etnologia e História, 11 [in press].

Callapez, P.M. 2012. Padrão 1 (Vila do Bispo): Estudo bioarqueológico de restos faunísticos de invertebrados marinhos num contexto arqueológico do Neolítico antigo [in press].

Carter, J.C.; Altaba, C.R.; Anderson, L.C.; AraúJo, R.; Biakov, A.S.; Bogan, A.E.; Campbell, D.C.; Campbell, M.; Jin-Hua, C.; Cope, C.W.; Delvene, G.; DiJKstra, H.; ZONG-JIE, F.; GARDNER, R.N.; GAVRILOVA, V.A.; GONCHArova, I.A.; Harries, P.J.; Hartman, J.H.; HaUtManN, M.; Hoeh, W.; Hylleberg, J.; BaO-YU, J.; Johnston, P.; KIRKENDAle, L.; KleEMANN, K.; KopPKA, J.; KŘÍŽ, J.; MACHADo, D.; Malchus, N.; Márouez-Aliaga, A.; Masse, J.-P.; Mcroberts, C.A.; Middelfart, P.U.; Mitchell, S.; NeVesskaja, L.A.; ÖZer, S.; Pojeta, JR., J.; PolubotKo, I.V.; Pons, J.M.; Popov, S.; SÁnchez, T.; SARTORI, A.F.; ScotT, R.W.; Sey, I.I.; SignORElli, J.H.; SilantieV, V.V.; SKelton, P.W.; Steuber, T.; Waterhouse, J.B.; Wingard, G.L. \& YANCEY, T. 2011. A Synoptical Classification of the Bivalvia (Mollusca). Paleontological Contributions, 4: $47 \mathrm{p}$.

CAYrÉ, P. 1981. Stocks de mollusques bivalves. In A. FonTANA (ed.), Milieu marin et ressources halieutiques de la République Populaire du Congo. Travaux et Documents de l'ORSTOM, 138: 313-322.

Danielsen, R.; Castilho, A.; Callapez, P.M. \& Dinis, P.M. 2008. Evolução da paisagem a norte do Cabo Mondego durante os últimos milhares de anos. In F.C. LOPES \& P.M. Callapez (eds.), Por terras da Figueira. Figueira da Foz: Kiwanis Clube da Figueira da Foz: 45-53.

Danielsen, R.; Castilho, A.M.; Dinis, P.M.; Almeida, A.C. \& CAllapeZ, P.M. 2011. Holocene interplay between a dune field and coastal lakes in the Quiaios - Tocha region, central littoral Portugal. The Holocene, 22 (4): 383-395.

Dias, J.M.A.; Boski, T.; Rodrigues, A. \& Magalhães, F. 2000. Coast line evolution in Portugal since the Last Glacial Maximum until present - a synthesis. Marine Geology, 170: 177-186.

FÉRUSSAC, A.E.J. 1821-1822. Tableaux Systématiques des Animaux Mollusques suivis d'un Prodrome Général pour tous les Mollusques Terrestres ou Fluviatiles Vivants ou Fossiles. Première Partie, Tableaux Systématiques Généraux. Paris: Arthus-Bertrand.
GIGNOUX, M. 1913. Les formations marines pliocenes et Quaternaires de l'Italie du sud et de la Sicilie. Annals de l'Universite de Lyon, n.s. 36: 1-633.

GranjA, H.M., 1998. Evidence for Late Pleistocene and Holocene sea-level, neotectonic and climate control in the coastal zone of northwest Portugal. Geologie en Mijnbouw, 77: 233-245.

Granja, H.M. \& De Groot, T.A.M. 1996. Sea-level rise and neotectonism in a Holocene coastal environment at Cortegaca Beach (NW Portugal): a case study. Journal of Coastal Research, 12: 160-170.

Hernandéz, J.M.; Rólan, E.; Swinnen, F.; Gómez, R. \& PÉREZ, J.M. 2011. Moluscos y Conchas Marinas de Canarias. Hackenheim, Germany: Conchbooks Eds.

Hicks, D.W.; Tunnell JR., J.W. \& Mcmahon, R.F. 2001. Population dynamics of the nonindigenous brown mussel Perna perna in the Gulf of Mexico compared to other world-wide populations. Marine Ecology Progress Series, 122: 181-192.

JERADINO, A. \& MAREAN, C.W. 2010. Shellfish gathering, marine paleoecology and modern human behavior: perspectives from cave PP13B, Pinnacle Point, South Africa. Journal of Human Evolution, 59 (3-4): 412-424.

KILbURN, R. \& RiPPEY, E. 1982. Sea shells of Southern Africa. Macmillan South Africa. Johannesburg, South Africa.

LANGeJAns, G.H.J.; NieKerk, K.L.; DusseldorP, G.L. \& THACKERAY, J.F. 2012. Middle Stone Age shellfish exploitation: Potential indications for mass collecting and resource intensification at Blombos Cave and Klasies River, South Africa. Quaternary International, 270: 80-94.

LinNÉ, C.A. 1758. Systema Naturae per Regna Tria Naturae, Secundum Classes, Ordines, Genera, Species, cum Characteribus, Differentiis, Synonymis, Locis. Tomus I-Regnum Animale. Editio Decima, reformata. Holmiae: Impensis Laurentii Salvii.

LourenÇO, C.R.; NicAstro, K.R.; SERrÃo, E.S. \& ZARDI, G.I. 2012. First record of the brown mussel (Perna perna) from the European Atlantic coast. Marine Biodiversity Records, 5: e39 (published online).

Macedo, M.C.C.; Macedo, M.I.C. \& Borges, J.P. 1999. Conchas marinhas de Portugal - Seashells of Portugal. Lisboa: Editorial Verbo.

MCQUAID, C.D.; LindSAY, J.R. \& LINDSAY, T.L. 2000. Interactive effects of wave exposure and tidal height on population structure of the mussel Perna perna. Marine Biology, 137: 925-932.

MOORE, R.C. (coord.) 1969. Treatise on Invertebrate Paleontology, Part N, Vol. 1. Boulder, Colorado: The Geological Society of America, Inc. and the University of Kansas.

NoBre, A. 1906. Mollusques et Brachiopodes du Portugal. Anais de Ciências Naturais, 10: 91-144.

Nobre, A. 1932. Moluscos marinhos de Portugal. Vol. I. Porto: Imprensa Portuguesa.

Nobre, A. 1938-40. Fauna malacológica de Portugal. I - Moluscos marinhos e das águas salobras. Porto: Companhia Editora do Minho.

NordsiECK, F. 1969. Die europäischen Meeresmuscheln. Vom Eismeer bis Kapverden, Mittelmeer und Schwarzes Meer. Stuttgart: Gustav Fischer Ed.

OTCHERE, F.A. 2003. Heavy metals concentration and burden in the bivalves (Anadara senilis, Crassostrea tulipa and Perna perna) from lagoons in Ghana. Model to describe mechanism of accumulation/excretion. African Journal of Biotechnology, 2 (9): 280-287. 
Poppe, G. \& Goto, Y. 1993. European Seashells. Vol. II - Scaphopoda, Bivalvia, Cephalopoda. Wiesbaden: Verlag Christa Hemmen.

Rafinesque, C.S. 1815. Analyse de la Nature ou Tableau de l'Univers et des Corps Organisés. Palermo: Jean Barravecchia. Ed.

RetZIUS, A.J. 1788. Dissertatio Historico-Naturalis Sistens Nova Testaceorum Genera. Quam Venia Ampliss. Facult. Philosophicae Praeside D. M. Andr. J. Retzio, Ad Publicum Examen Defert Laurentius Münter Philipsson Scanus. Lundae: Typis Berlingianis.

RiUs, M.; KAEHLER, S. \& MCQUAID, C.D. 2006. The relationship between human exploitation pressure and condition of mussel populations along the south coast of South Africa. South African Journal of Science, 102 (3-4): 130-136.

Rodríguez, R.G. \& SÁNCHEZ, J.M. 1997. Moluscos bivalvos de Canárias. Las Palmas: Cabildo Insular de Gran Canaria.

Rolán, E. \& Ryall, P. 1999. Checklist of the Angolan marine molluscs. Reseñas Malacológicas, 10: 1-132.

SidDALL, S.E. 1980. A clarification of the genus Perna (Mytilidae). Bulletin of Marine Science 30(4): 858-870.

Sidoumou, Z.; Gnassia-Barelli, M.; Siau, Y.; Morton, V.; RoMEO, M. 2006. Heavy metal concentrations in molluscs from the Senegal coast. Environmental International, 32: 384-387.

SouZA, R.C.C.; Fernandes, F.C. \& Silva, E.P. 2003. A study on the occurrence of the brown mussel Perna perna on the sambaquis of the Brazilian coast. Revista do Museu de Arqueologia e Etnologia, São Paulo, 13: 3-24.

SPRY, J.F. 1964. The sea shells of Dar es Salaam: Part 2: Pelecypoda (Bivalves). Tanganyika Notes and Records, 63: $41 \mathrm{p}$.

STEYN, D.G. \& Lussi, M. 1998. Marine shells of South Africa. Hartebeespoort, South Africa: Ekogilde Publications.

VAn Aartsen, J.J.; MenKhorst, H.P. \& GitTenberger, E. 1984. The marine Mollusca from the Bay of Algeciras, Spain, with general notes on Mitrella, Marginellidae and Turridae. Basteria, suppl. 2: 1-135.

VAKILY, J.M. 1989. The biology and culture of mussels of the genus Perna. International Center for Living Aquatic Resources Management - ICLARM Studies and Reviews, 17: 1-63.

Zazo, C.; Goy, J.L.; DABrio, C.J.; BARdají, T.; Hillaire-MarCel, C.; Ghaleb, B.; GonzÁlez-Delgado, J.A. \& Soler, V. 2003. Pleistocene raised marine terraces of the Spanish Mediterranean and Atlantic coasts: records of coastal uplift, sea-level highstands and climate changes. Marine Geology, 194 (1-2): 103-133. 


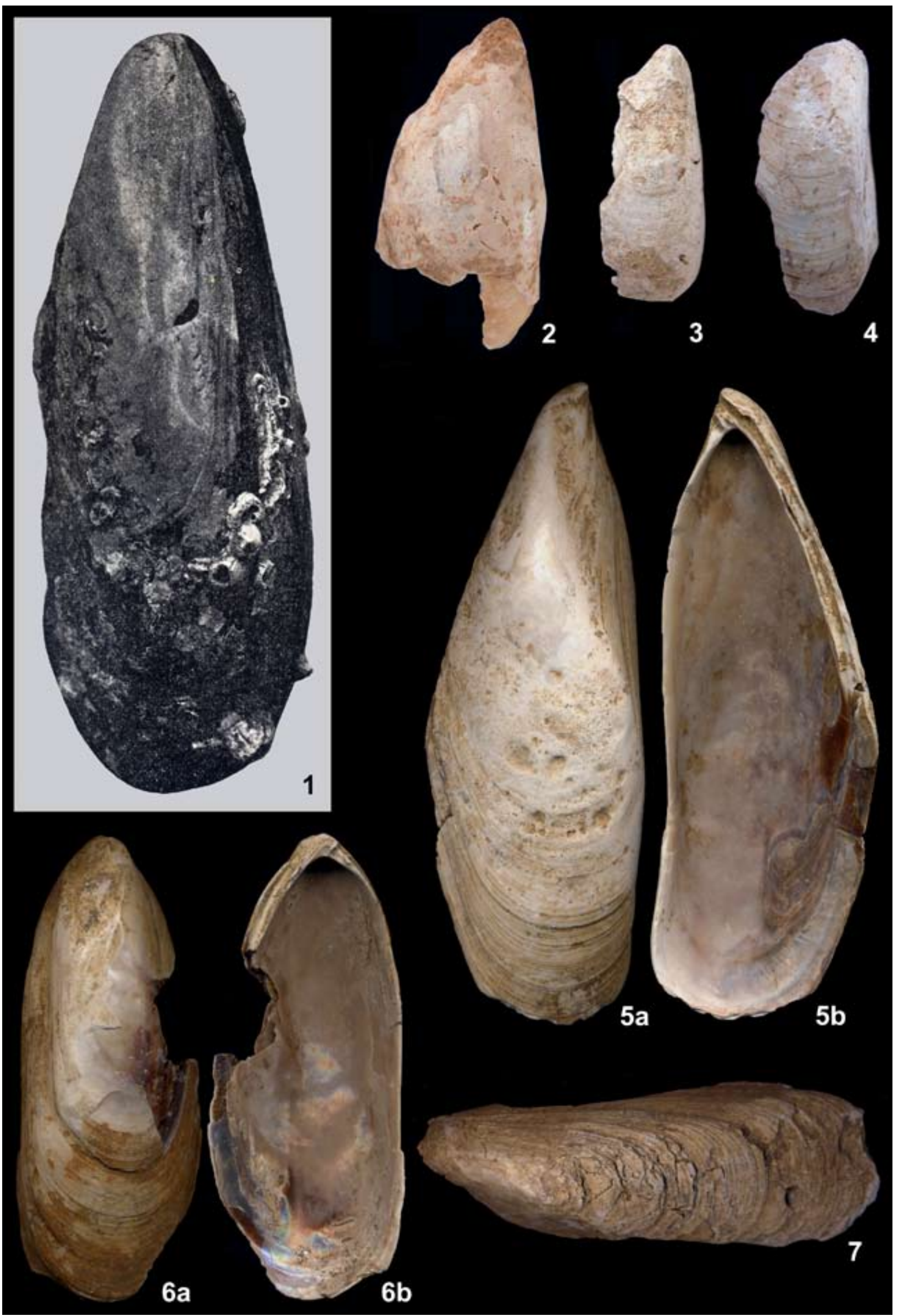


Occurrences of the Amphi-Atlantic brown mussel Perna perna (LINNÉ, 1758) (Mollusca, Bivalvia) in South Portugal since the Atlantic "climatic optimum"

Plate 1. Fig. 1 - Perna perna (LINNÉ, 1758). Reproduction of the specimen figured by A. Nobre (1932, 1938-40) as Mytilus pictus Born. Figs. 2-4 - Perna perna (LinNÉ, 1758). Specimens from the Ancient Neolithic site of Padrão I (Sagres - Vila do Bispo, West Algarve). Figs. 5-7 - Perna perna (LinNé, 1758). Specimens from the XII century kitchen middens of the Arrifana Ribāt Islamic site (Aljezur, West Algarve). All specimens are represented in natural size.

Plate 1. Fig. 1 - Perna perna (LinNé, 1758). Reprodução do espécime figurado como Mytilus pictus BorN, por A. Nobre (1932, 1938-40). Figs. 2-4 - Perna perna (LinNÉ, 1758). Espécimes do arqueossítio Padrão I (Neolítico Antigo, Sagres - Vila do Bispo, Algarve Ocidental). Figs. 5-7 - Perna perna (LINNÉ, 1758). Espécimes dos concheiros do arqueossítio do Ribāt islâmico da Arrifana (século XII, Aljezur, Algarve Ocidental). Todos os espécimes estão representados em tamanho natural. 